\title{
ANALISIS PROFITABILITAS DAN LEVERAGE TERHADAP MANAJEMEN LABA PADA PERUSAHAAN MANUFAKTUR DI BURSA EFEK INDONESIA
}

\author{
Olifia Tala $^{1}$, Herman Karamoy ${ }^{2}$ \\ ${ }^{1}$ Program Studi Akuntansi, Fakultas Ekonomi, Universitas Negeri Manado, Tonsaru, Tondano, Indonesia \\ ${ }^{2}$ Pendidikan Profesi Akuntansi, Fakultas Ekonomi dan Bisnis, Universitas Sam Ratulangi, Jl. Kampus Bahu, \\ Manado, 95115, Indonesia \\ E-mail : olivia_tala@yahoo.com
}

\begin{abstract}
This study aimed to analyze the profitability and leverage to earnings management. The population of this study is chemical and basic industry sectors manufacturing companies who were registered in Indonesian Stock Exchange from 2012 to 2015. 14 companies in chemical and basic industry sectors manufacturing companies category was used as sample, conducted by using purposive sampling method. Data were analyzed using multiple linear regression analysis with SPSS version 24. The results showed that profitability affects significantly, and leverage have no significant effects on earnings management.
\end{abstract}

Keywords: Profitability, Leverage, Earnings Management.

\section{PENDAHULUAN}

Pasar modal merupakan salah satu wadah untuk berinvestasi. Menurut Robert Ang (1997), pasar modal adalah suatu situasi dimana para penjual dan pembeli dapat melakukan negosiasi terhadap pertukaran suatu komoditas atau kelompok komoditas, dan komoditas yang dipertukarkan disini adalah modal, dimana modal adalah sesuatu yang digunakan oleh perusahaan sebagai sumber dana untuk melaksanakan kegiatan perusahaan.

Penggunaan penilaian dan estimasi dalam akuntansi akrual mengizinkan manajer untuk menggunakan informasi dalam dan pengalaman mereka untuk menambah kegunaan angka akuntansi. Dimana manajer yang bertindak sebagai pengelola perusahaan, tentunya lebih banyak mengetahui informasi internal dan prospek perusahaan di masa yang akan datang dibandingkan pemiliknya dan nantinya manajer akan memberikan laporan mengenai kondisi perusahaan kepada pemilik perusahaan sebagai bentuk pertanggungjawaban kepada pemegang saham. Namun, beberapa manajer menggunakan kebebasan ini untuk mengubah angka akuntansi terutama laba, untuk keuntungan pribadi, sehingga mengurangi kualitas dan relevansi informasi dan pemilik selaku pemegang saham akan salah menafsirkan kondisi perusahaan tersebut akibat adanya asimetri informasi.

Untuk mendukung penelitian ini, data yang digunakan adalah data sekunder yang diambil dari laporan keuangan tahunan perusahaan di situs www.idx.co.id, dan juga dari Indonesia Capital Market Directory (ICMD) yang disediakan kantor IDX Manado. Berdasarkan latar belakang pemilihan judul, maka selanjutnya rumusan masalah dalam penelitian ini adalah sebagai berikut:

1. Apakah profitabilitas berpengaruh terhadap manajemen laba pada perusahaan manufaktur yang terdaftar di Bursa Efek Indonesia?

2. Apakah leverage berpengaruh terhadap manajemen laba pada perusahaan manufaktur yang terdaftar di Bursa Efek Indonesia?

\section{TINJAUAN PUSTAKA}

Akuntansi biasanya disebut sebagai bahasa bisnis atau sering disebut sebagai bahasa dari keputusan keuangan. Hal ini disebabkan banyak aspek sehari-hari yang didasarkan pada 
akuntansi, seperti : perencanaan keuangan pribadi, biaya pendidikan, investasi pinjaman, pajak penghasilan dan masih banyak lainnya. Akuntansi menurut Mulyadi (2005:18) adalah suatu sistem yang mengukur kuantitas-kuantitas bisnis, memproses informasi tersebut ke dalam bentuk laporan-laporan, mengkomunikasikannya kepada para pengambil keputusan.

Laba merupakan indikator kinerja yang dilakukan manajemen dalam mengelola kekayaan perusahaan. Laba berfungsi untuk mengukur efektivitas bersih dari sebuah usahan bisnis. Laba juga akan menjamin pasokan modal di masa depan untuk inovasi dan perluasan usaha (Pearce, et.al., 2010). Kinerja suatu perusahaan dapat dilihat dari tingkat perolehan laba. Laba atau rugi sering dimanfaatkan sebagai ukuran untuk menilai prestasi perusahaan. Unsur-unsur yang menjadi bagian pembentuk laba adalah pendapatan dan biaya. Dengan mengelompokkan unsur-unsur pendapatan dan biaya, akan dapat diperoleh hasil pengukuran laba yang berbeda antara lain: laba kotor, laba operasional, laba sebelum pajak, dan laba bersih. Profitabilitas merupakan hasil bersih dari sejumlah kebijakan dan keputusan perusahaan. Profitabilitas merupakan faktor yang seharusnya mendapat perhatian penting, karena untuk dapat berjalannya suatu perusahaan, perusahaan tersebut harus berada dalam keadaan yang menguntungkan. Tanpa adanya keuntungan (profit), maka sulit untuk perusahaan menarik modal dari luar. Profitabilitas adalah kemampuan perusahaan memperoleh laba dalam hubungannya dengan penjualan, total aset maupun modal sendiri (Sartono dalam Herni dan Yulius Kurnia Susanto, 2008).

Leverage menggambarkan sumber dana operasi yang digunakan oleh perusahaan. Leverage merupakan rasio antara total kewajiban dengan total asset. Kebijakan hutang merupakan salah satu alternatif pendanaan perusahaan selain menjual saham di pasar modal. Hutang yang dipergunakan secara efektif dan efisien akan meningkatkan nilai dari suatu perusahaan. Perusahaan yang memiliki hutang yang tinggi akan memilih kebijakan akuntansi dengan menggeser laba masa depan ke masa sekarang.

Manajemen laba merupakan tindakan manajemen yang dapat mempengaruhi angka laba yang dilaporkan. Scott (2006: 344) mendefinisikan manajemen laba sebagai berikut: manajemen laba merupakan pemilihan kebijakan akuntansi oleh manajer dari Standar Akuntansi Keuangan yang ada dan secara alamiah dapat memaksimalkan utilitas mereka dan atau nilai pasar perusahaan.

\section{HIPOTESIS DAN MODEL}

Berdasarkan permasalahan yang dirumuskan serta tujuan yang ingin dicapai, maka hipotesis penelitian sebagaimana berikut ini dikemukakan:

$\mathrm{H}_{\mathrm{a} 1}$ : Profitabilitas berpengaruh signifikan terhadap manajemen laba.

$\mathrm{H}_{01}$ : Profitabilitas tidak berpengaruh signifikan terhadap manajemen laba.

$\mathrm{H}_{\mathrm{a} 2}$ : Leverage berpengaruh signifikan terhadap manajemen laba.

$\mathrm{H}_{02}$ : Leverage tidak berpengaruh signifikan terhadap manajemen laba.

Berdasarkan pemahaman, tujuan, literatur yang dibahas sebelumnya, maka dikembangkan konseptual penelitian sebagaimana diperlukan pada Gambar 2.1 :

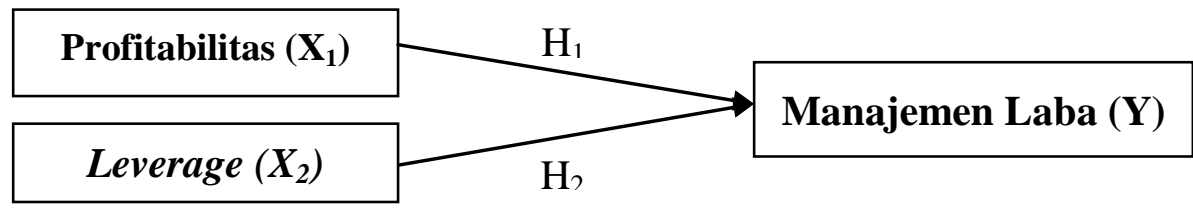

Gambar 1. Kerangka Konseptual 


\section{METODE PENELITIAN}

\subsection{Data}

Penelitian ini menggunakan data kuantitatif berupa data keuangan dari laporan perusahaan manufaktur sektor industri dasar dan kimia yang terdapat di Bursa Efek Indonesia. Tempat penelitian di Bursa Efek Indonesia (BEI) yang berada di kota Manado, dan juga pencarian data melalui website perusahaan-perusahaan. Waktu penelitian berturutturut dari tahun 2012 sampai dengan tahun 2015. Data adalah sekumpulan informasi yang diperlukan untuk pengambilan keputusan (Kuncoro, 2003:124). Data diperoleh dengan mengukur nilai satu atau lebih variabel dalam sampel (atau populasi). Data dapat diklasifikasikan menjadi dua golongan, yaitu sebagai berikut :

1. Data kuantitatif. Data kuantitatif adalah data yang bersumber pada biaya-biaya serta laporan lain yang disajikan dalam bentuk angka-angka (skala numerik).

2. Data kualitatif. Data kualitatif adalah data yang bersifat deskriptif atau berbentuk uraian atau penjelasan serta tidak dapat diukur dalam skala numerik.

Dalam penelitian ini, data yang digunakan adalah data kuantitatif berupa data keuangan dari laporan perusahaan manufaktur sektor industri dasar dan kimia yang terdaftar di Burasa Efek Indonesia (BEI) berturut-turut dari tahun 2012 sampai tahun 2015. Sumber data di bagi menjadi dua, yaitu sebagai berikut :

1. Data Primer : Data yang diperoleh dari kantor Bursa Efek Indonesia yang berada di Manado, yang merupakan objek penelitian ini, berupa laporan keuangan perusahaan manufaktur sektor industri dasar dan kimia.

2. Data Sekunder : data yang telah dikumpulkan oleh lembaga pengumpul data dan dipublikasikan kepada masyarakat pengguna data, maupun data yang didapat dari buku dan informasi lainnya, maupun perpustakaan. Data yang digunakan dalam penelitian ini berupa data sekunder yang diambil dari laporan keuangan tahunan perusahaan. Data yang digunakan merupakan data yang telah diaudit 2012 - 2015 berturut-turut, dan diperoleh dari Indonesia Capital Market Directory (ICMD) dan www.idx.co.id.

Teknik pengambilan data dalam penellitian ini berupa dokumentasi, dikarenakan data yang diambil merupakan data sekunder. Metode pengambilan sampel di gunakan data pooling. kombinasi antara data runtut waktu dan silang tempat disebut data pooling. Data runtut waktu (time-series) yaitu data yang secara kronologis disusun menurut waktu pada suatu variabel tertentu berupa periode pengamatan yang runtut dari tahun $2012-2015$. Data silang tempat menunjukkan jumlah sampel yang diambil dalam penelitian.

\subsection{Variabel dan Pengukuran}

1. Dechow, Sloan dan Sweeney (1995) dalam Permatasari (2005) menyatakan bahwa modifikasi model Jones (1991) merupakan model yang paling kuat dalam mendeteksi manajemen laba secara relatif terhadap model Healy, model DeAngelo dan model Jones orisinil. Modifikasi model Jones merupakan model yang paling tepat untuk memisahkan kebijakan akrual oleh manajemen dengan akrual yang terjadi akibat perubahan skala ekonomi perusahaan. Model modifikasi Jones adalah sebagai berikut:

$$
\frac{T A_{i t}}{A_{i t-1}}=a_{i}\left(\frac{1}{A_{i t-1}}\right)+b_{1 i}\left(\frac{\Delta R e v_{i t}-\Delta R e c_{i t}}{A_{i t-1}}\right)+b_{2 i}\left(\frac{P P E_{i t}}{A_{i t-1}}\right)+\varepsilon_{i t}
$$

Keterangan:

TAit : total akrual perusahaan i pada periode $\mathrm{t}$

$\triangle \mathrm{REVit} \quad$ : pendapatan perusahaan i pada periode $\mathrm{t}$ dikurangi pendaptan periode $\mathrm{t}-1$

$\triangle$ RECit $\quad$ : piutang dagang perusahaan i periode $t$ dikurangi piutang dagang periode $\mathrm{t}-1$ 
PPEit : aktiva tetap (gross) perusahaan i pada periode $\mathrm{t}$

Ait-1 : total aktiva perusahaan i pada periode $\mathrm{t}-1$

$\varepsilon$ it $\quad:$ nilai residu perusahaan i pada periode $\mathrm{t}$

Total akrual untuk periode $\mathrm{t}$ dapat dinyatakan dalam persamaan berikut:

$$
\mathrm{TA}_{\mathrm{it}}=\mathrm{NI}_{\mathrm{it}}-\mathrm{CFO}_{\mathrm{it}}
$$

Keterangan:

TAit : total akrual perusahaan i pada tahun $\mathrm{t}$

NIit : laba bersih perusahaan i pada periode $\mathrm{t}$

CFOit $\quad$ : arus kas dari kegiatan operasi perusahaan i pada periode $\mathrm{tt}$

Seluruh variabel dibagi dengan aset total awal periode.

2. Pengukuran variabel profitabilitas adalah rasio antara laba bersih setelah pajak dengan total aset sehingga didapat persentase (Etty M. Nasser dan Tobia Parulia, 2006).

$$
\text { Return On Asset }(\mathrm{ROA})=\frac{\text { Laba Bersih setelah Pajak }}{\text { Total Aset }}
$$

3. Rasio leverage dihitung seperti di bawah ini:

$$
\text { Debt to Asset Ratio (DAR) }=\frac{\text { Total Hutang }}{\text { Total Aset }}
$$

\subsection{Metode Analisis}

Analisis data ini menggunakan bantuan komputer dengan software program SPSS for windows tanpa menggunakan perhitungan manual. Untuk penelitian ini, dilakukan Uji Asumsi Klasik Regresi. Uji asumsi klasik digunakan untuk mengetahui normalitas residual, multikolinieritas, autokorelasi dan heteroskedastis pada model regresi. Signifikansi adalah besarnya probabilitas atau peluang untuk memperoleh kesalahan dalam mengambil keputusan. Jika pengujian menggunakan tingkat signifikansi 0.05 artinya peluang memperoleh kesalahan maksimal 5\%. Dengan kata lain bahwa 95\% keputusan adalah benar. Uji Normalitas. Uji normalitas pada model regresi digunakan untuk menguji apakah nilai residual yang dihasilkan dari regresi terdistribusi normal atau tidak. Model regresi yang baik adalah yang memiliki nilai residual yang terdistribusi secara normal. Beberapa metode uji normalitas yaitu, dengan melihat penyebaran data pada sumber diagonal pada grafik Normal P-P Plot of regression standardized residual atau dengan uji One Sample KolmogorovSmirnov.

Uji Multikolinieritas. Multikolinnieritas artinya antarvariabel independen yang terdapat dalam model regresi memiliki hubungan linier yang sempurna atau mendekati sempurna (koefisien korelasinya tinggi atau bahkan 1). Model regresi yang baik seharusnya tidak terjadi korelasi sempurna atau mendekati sempurna di antara variabel bebasnya. Konsekuensi adanya multikolinieritas adalah koefisien korelasi tidak tertentu dan kesalahan menjadi sangat besar.

Uji Autokorelasi. Autokorelasi merupakan korelasi antara anggota observasi yang disusun menurut waktu atau tempat. Model regresi yang baik seharusnya tidak terjadi autokorelasi. Metode pengujian menggunakan Uji Durbin-Watson (DW Test). 
Uji Heteroskedastisitas. Heteroskedastisitas adalah varian residual yang tidak sama pada semua pengamatan di dalam model regresi. Regresi yang baik seharusnya tidak terjadi heteroskedstisitas.

Uji F. ANOVA atau analisis varian, yaitu koefisien regresi secara bersama-sama (Uji F) untuk menguji signifikansi pengaruh beberapa variabel independen terhadap variabel dependen. Pengujian menggunakan tingkat signifikansi 0.05 .

Uji t. Uji t digunakan untuk mengetahui apakah secara parsial variabel $X_{1}$ dan $X_{2}$ berpengaruh signifikan atau tidak terhadap Y. Pengujian menggunakan tingkat signifikansi 0.05 dan 2 sisi..

\section{HASIL ANALISIS DAN PEMBAHASAN}

\subsection{Hasil Analisis}

Populasi yang digunakan dalam penelitian ini adalah seluruh perusahaan yang terdaftar di Bursa Efek Indonesia (BEI), dan menerbitkan laporan keuangan tahunan tahun 2012 - 2015. Sampel yang digunakan adalah perusahaan manufaktur sektor industri dasar dan kimia yang terdaftar di Bursa Efek Indonesia. Berdasarkan data yang diperoleh dari Indonesia Capital Market Directory (ICMD), terdapat 64 perusahaan manufaktur sektor industri dasar dan kimia yang terdaftar di BEI selama periode $2012-2015$.

\section{Data Hasil Pemilihan Sampel}

\begin{tabular}{clr}
\hline No. & \multicolumn{1}{c}{ Keterangan } & Jumlah \\
\hline 1 & $\begin{array}{l}\text { Jumlah perusahaan manufaktur sektor industri dasar dan } \\
\text { kimia yang tercatat di BEI tahun 2011 - 2014 }\end{array}$ & 64 \\
2 & $\begin{array}{l}\text { Jumlah perusahaan manufaktur sektor industri dasar dan } \\
\text { kimia yang tidak memenuhi kriteria } \\
\quad \text { Jumlah sampel yang digunakan dalam penelitian }\end{array}$ & 50 \\
\hline
\end{tabular}

Dalam penelitian ini, uji normalitas dideteksi analisis statistik non parametrik KolmogorovSmirnov Z (1-Sample K-S).

Uji Normalitas One-Sample Kolmogorov-Smirnov Test

\begin{tabular}{|c|c|c|}
\hline & & 56 \\
\hline \multirow[t]{2}{*}{ Normal Parameters $^{\mathrm{a}, \mathrm{b}}$} & Mean & .0000000 \\
\hline & Std. Deviation & .05849417 \\
\hline \multirow[t]{3}{*}{ Most Extreme Differences } & Absolute & .092 \\
\hline & Positive & .092 \\
\hline & Negative & -.073 \\
\hline \multicolumn{2}{|c|}{ Test Statistic } & .092 \\
\hline \multicolumn{2}{|c|}{ Asymp. Sig. (2-tailed) } & $.200^{\mathrm{c}, \mathrm{d}}$ \\
\hline
\end{tabular}

\footnotetext{
a. Test distribution is Normal.

b. Calculated from data.

c. Lilliefors Significance Correction.

$\mathrm{d}$. This is a lower bound of the true significance.

Sumber: data yang diolah dengan SPPS 24.0
}

Dari output di atas dapat diketahui bahwa nilai signifikansi (Asymp.Sig 2-tailed) sebesar 0.200. Karena nilai signifikansi lebih dari 0.05, nilai residual terdistribusi dengan normal. 
Uji Autokorelasi Model Summary ${ }^{\text {b }}$

\begin{tabular}{rr|r|r|r|r} 
Model & $\mathrm{R}$ & \multicolumn{1}{c|}{ R Square } & Adjusted R Square & $\begin{array}{c}\text { Std. Error of the } \\
\text { Estimate }\end{array}$ & \multicolumn{1}{c}{ Durbin-Watson } \\
\hline 1 & $.518^{\mathrm{a}}$ & .268 & .241 & .05959 & 1.613 \\
\hline
\end{tabular}

a. Predictors: (Constant), DAR, ROA

b. Dependent Variable: ML

Sumber: data yang diolah dengan SPPS 24.0

Dari output di atas dapat diketahui nilai Durbin-Watson sebesar 1.613, hasilnya tidak ada autokorelasi pada model regresi.

\begin{tabular}{|c|c|c|c|c|c|c|c|c|}
\hline \multicolumn{9}{|c|}{ Uji Multikolinearitas Coefficients ${ }^{\mathrm{a}}$} \\
\hline & \multirow[b]{2}{*}{ Model } & \multicolumn{2}{|c|}{ Unstandardized Coefficients } & \multirow{2}{*}{$\begin{array}{c}\text { Standardized } \\
\text { Coefficients } \\
\text { Beta }\end{array}$} & \multirow[b]{2}{*}{$\mathrm{T}$} & \multirow[b]{2}{*}{ Sig. } & \multicolumn{2}{|c|}{ Collinearity Statistics } \\
\hline & & $\mathrm{B}$ & Std. Error & & & & Tolerance & VIF \\
\hline 1 & (Constant) & -.118 & .035 & & -3.317 & .002 & & \\
\hline & $\mathrm{ROA}$ & .613 & .142 & 640 & 4.305 & .000 & .625 & 1.601 \\
\hline & DAR & .124 & .066 & .281 & 1.887 & .065 & .625 & 1.601 \\
\hline
\end{tabular}

a. Dependent Variable: ML

Sumber: data yang diolah dengan SPPS 24.0

Suatu model regresi dikatakan bebas dari masalah multikolinieritas jika korelasi antar variabel independennya lebih kecil dari 0.5. Selain itu dapat diketahui melalui besaran VIF dan Tolerance, dimana jika nilai VIF dan Tolerance lebih dari 0.1, maka model regresi bebas multikolinieritas. Dengan melihat nilai VIF $<10$. Maka dapat disimpulkan bahwa tidak terjadi multikolinieritas antar variabel bebas.

Uji F ANOVA ${ }^{\mathrm{a}}$

\begin{tabular}{cr|r|r|r|r|r} 
& Model & Sum of Squares & Df & Mean Square & F & Sig. \\
\hline 1 & .069 & 2 & .034 & 9.716 & $.000^{b}$ \\
\cline { 2 - 7 } & Regression & .188 & 53 & .004 & & \\
\hline & Residual & .257 & 55 & & & \\
\hline Total & & 55 & & & \\
\hline
\end{tabular}

a. Dependent Variable: ML

b. Predictors: (Constant), DAR, ROA

Sumber: data yang diolah dengan SPPS 24.0

$\mathrm{F}_{\text {hitung }}>\mathrm{F}_{\text {tabel }}(9.716>3.172)$ dan signifikansi $<0.05(0.000<0.05)$, maka $\mathrm{H}_{0}$ ditolak. Jadi dapat disimpulkan bahwa Profitabilitas dan Leverage secara bersama - sama berpengaruh terhadap manajemen laba.

\begin{tabular}{|c|c|c|c|c|c|c|c|c|}
\hline \multicolumn{9}{|c|}{ Uji t - Coefficients ${ }^{\mathrm{a}}$} \\
\hline & \multirow[b]{2}{*}{ Model } & \multicolumn{2}{|c|}{ Unstandardized Coefficients } & \multirow{2}{*}{$\begin{array}{c}\text { Standardized } \\
\text { Coefficients } \\
\text { Beta }\end{array}$} & \multirow[b]{2}{*}{$\mathrm{t}$} & \multirow[b]{2}{*}{ Sig. } & \multirow{2}{*}{$\begin{array}{l}\text { Collinearity } \\
\text { Tolerance }\end{array}$} & \multirow{2}{*}{$\begin{array}{l}\text { Statistics } \\
\text { VIF }\end{array}$} \\
\hline & & B & Std. Error & & & & & \\
\hline 1 & (Constant) & -.118 & .035 & & -3.317 & .002 & & \\
\hline & ROA & .613 & .142 & .640 & 4.305 & .000 & .625 & 1.601 \\
\hline & DAR & .124 & .066 & .281 & 1.887 & .065 & .625 & 1.601 \\
\hline
\end{tabular}

a. Dependent Variable: ML

Sumber: data yang diolah dengan SPPS 24.0

Pengujian koefisien variabel Profitabilitas.

Nilai $t_{\text {hitung }}>\mathrm{t}_{\text {tabel }}(4.305>2.006)$ dan signifikansi $<0.05(0.000<0.05)$, maka $\mathrm{H}_{0}$ ditolak, jadi dapat disimpulkan bahwa Profitabilitas secara parsial berpengaruh terhadap Manajemen 
Laba. Nilai $t_{\text {hitung }}$ positif artinya berpengaruh positif, yaitu jika profitabilitas meningkat, maka manajemen laba juga akan meningkat.

Pengujian koefisien variabel Leverage

Nilai $\mathrm{t}_{\text {hitung }}<\mathrm{t}_{\text {tabel }}(1.887<2.006)$ dan signifikansi $>0.05(0.65>0.05)$, maka $\mathrm{H}_{0}$ ditolak, jadi leverage secara parsial tidak berpengaruh terhadap manajemen laba. Interpretasi model linier berganda seperti yang disajikan pada Tabel 5.6, sehingga dapat dituliskan persamaan regresinya sebagai berikut:

$$
\text { ML = -0.118 + 0.613ROA + 0.124DAR }
$$

Nilai konstanta $\alpha$ adalah -0.118 menyatakan bahwa jika profitabilitas dan leverage nilainya adalah 0 , maka manajemen laba nilainya -0.118. Nilai koefisien regresi variabel profitabilitas bernilai positif yaitu 0.613 ini menunjukkan bahwa jika variabel profitabilitas meningkat sebesar 1 satuan, maka akan meningkatkan manajemen laba sebesar 0.613 satuan dengan asumsi variabel independen lain nilainya tetap. Nilai koefisien regresi variabel leverage bernilai positif yaitu 0.124 ini menunjukkan bahwa jika variabel leverage meningkat sebesar 1 satuan, maka akan meningkatkan manajemen laba sebesar 0.124 satuan dengan asumsi variabel independen lain nilainya tetap.

\subsection{Pembahasan}

Pengujian di atas yang menyangkut profitabilitas dan leverage secara simultan berpengaruh signifikan terhadap manajemen laba pada perusahaan manufaktur sektor industri dasar dan kimia di Bursa Efek Indonesia. Secara simultan dengan menggunakan uji F dengan kriteria signifikan 0.05. Hasil pengujian variabel bebas profitabilitas dan leverage mempunyai tingkat signifikansi 0.000 . Hal ini berarti $0.000<\alpha$ : 5\% (0.05). Pengaruh ini ditinjau dari koefisien determinasi dimana nilai determinasi sebesar $26.8 \%$ dapat dijelaskan oleh variabel profitabilitas dan leverage. Sedangkan sisanya $73.2 \%(100 \%$ - 26.8\%) dijelaskan oleh variabel lain yang tidak dimasukkan dalam penelitian ini.

Dari tabel dapat dilihat bahwa variabel profitabilitas berpengaruh signifikan terhadap manajemen laba. Oleh karena itu, hasil pengujian ini sesuai dengan hipotesis kedua, yang mengatakan bahwa profitabilitas berpengaruh signifikan terhadap manajemen laba. Menurut data profitabilitas perusahaan manufaktur sektor industri dasar dan kimia, tingkat kecenderungan naik pada profitabilitas perusahaan. Karena profitabilitas naik maka kecenderungan untuk manajer perusahaan akan melakukan manajemen laba. secara parsial dapat disimpulkan bahwa hipotesis $\mathrm{H}_{\mathrm{a}}$ diterima atau $\mathrm{H}_{0}$ ditolak.

\section{KESIMPULAN DAN SARAN \\ 6.1. Kesimpulan}

Profitabilitas dan Leverage secara bersama-sama (simultan) berpengaruh terhadap Manajemen Laba. Secara parsial Profitabilitas berpengaruh terhadap Manajemen Laba, sedangkan Leverage secara parsial tidak berpengaruh terhadap Manajemen Laba.

\subsection{Saran}

1. Untuk peneliti selanjutnya disarankan untuk dapat memperoleh sampel yang lebih besar dari populasi suatu pengamatan.

2. Untuk penelitian selanjutnya sampel yang digunakan tidak hanya pada industri manufaktur saja, melainkan industri lain yang listing di Bursa Efek Indonesia (BEI).

3. Menambah variabel yang dapat memperkuat pengaruh variabel independen terhadap variabel dependen atau manajemen laba. 


\section{DAFTAR PUSTAKA}

Ang, Robert. 1997. Buku Pintar: Pasar Modal Indonesia. Jakarta: Media Soft Indonesia.

Dechow, Patricia M., R.G. Sloan and A.P. Sweeney, (1995), dalam Ika Permatasari (2005).

"Manajemen Laba dan Status Keterlambatan Perusahaan Dalam Menyampaikan Laporan Keuangan Tahunan". Jurnal akuntansi dan keuangan Indonesia. Julidesember 2005.

Etty M. Nasser, Tobia Parulian, (2006). "Pengaruh Faktor-Faktor Internal Perusahaan Terhadap Income Smoothing”, Media Riset Akuntansi, Auditing, dan Informasi, 6(1).

Indonesia Capital Market Directory (ICMD) 2011 - 2015.

Kuncoro, Mudrajad. 2003. Metode Riset untuk Bisnis dan Ekonomi. Jakarta: Salemba Empat. Mulyadi, 2005. Akuntansi Biaya Jakarta: Salemba empat.

Pearce, C.L. et al. 2010. Drucker Difference: Inspirasi Manajemen Terbesar di Dunia Bagi Pemimpin Saat Ini, Ufuk Press. Jakarta.

Priyatno, Duwi. 2014. SPSS 22 Pengolah Data Terpraktis, Cetakan Pertama. Yogyakarta : ANDI.

Sartono, dalam herni dan Yulius kurnia susanto (2008). "Pengaruh Struktur Kepemilikan Publik, Praktik Pengelolaan Perusahaan, Jenis Industri, Ukuran Perusahaan, Profitabilitas dan Resiko Keuangan Terhadap Tindakan Perataan Laba". Jurnal ekonomi dan bisnis Indonesia.

Scott William R. 2006. Financial Accounting Theory. Edisi Keempat. USA: Prentice Hall. www.idx.go.id 